\title{
„Shape Up Somerville”: Egy egészséges közösség építése és fenntartása - cikkismertetés
}

\author{
Shape Up Somerville: Building and Sustaining a Healthy Community - \\ paper review
}

Ismerteti: Kasza Katalin $\square$

Országos Közegészségügyi Intézet

Szerzők: Chomitz VR, Garnett BR, Arsenault L, Hudson D, et al.

Megjelenés: https://www.somervillema.gov/sites/default/files/shape-up-somerville-story.pdf, 2013

Beküldve: 2018. 04. 22.

doi: 10.24365/ef.v59i3.283

Kulcsszavak: többszintű, közösségi alapú, elhízás megelőzési modell, egészségfejlesztés

Keywords: multi-level, community-based, obesity prevention model, health promotion

Jelen cikk röviden ismerteti az Amerikai Egyesült Államokban (USA) elismertté, ezáltal pedig jó gyakorlattá vált „Shape Up Somerville” (továbbiakban: SUS) elnevezésű többszintű, közösségi-alapú, elhízás megelőzési program több mint 15 évet felölelő eseményeit, valamint tanulságait.

A SUS program során iskolákat, élelmiszerkörnyezetet, épített környezetet és közösségeket érintő projektek valósultak meg Somerville városában, melyek mindegyikének fő célkitűzése az egészséges táplálkozás és aktív életmód előmozdítása volt, párhuzamosan az egyéni, a családi, az iskolai, a munkahelyi és közösségi színtereken a folyamatokban résztvevő lehető legtöbb szereplő bevonása révén. A program még jelenleg is megszakítás nélkül múködik. A következőkben a programot négy fázisra osztva ismertetjük, melyek az előkészítés (1998-2002), a megvalósítás (2002-2005), a program kiterjesztés (2006-2009) és a közösségi fenntartás (2010-től) szakaszai.

Az elmúlt évtizedekben a gazdasági növekedés, trendek hatására ugrásszerüen emelkedett az elhízott felnőttek és gyermekek aránya az USAban, amely probléma az alacsony szocio-ökonómiai státuszú csoportokat, jellemzően az etnikai kisebbségek tagjait gyakrabban érintette. Mivel ezek a negatív változások Somervilleben is megfigyelhetők voltak, a városvezetés tapasztalt népegészségügyi szakértőkhöz fordult támogató segítségért.

A program előkészítési szakaszában megalakult a "Táplálkozás és fizikai aktivitás" munkacsoport a helyi népegészségügyi szakemberekből és közösségi szószólókból, akik a rendszeresen megszervezett találkozóikat az elhízás megelőzés témája köré építették. A munkacsoport 1999-ben egy éves támogatást nyert a helyi szükségletek, igények és lehetőségek felmérésére, így elkészítették az „Erőforrás-útmutatót”i,1, amely a helyben elérhető, az egészséges táplálkozást és aktív életmódot elősegítő, vagy az elhízás kezelésére szolgáló lehetőségeket foglalta magában. Számos nemzeti

\footnotetext{
'Az „Erőforrás-útmutató” megfeleltethető a helyzetképnek, amely a közösségi egészségtervezés ciklikus folyamatának első lépését, azaz a tervezés feltételeinek, körülményeinek értékelését és az adatgyűjtést, valamint második lépését, a közösség problémáinak azonosítását és rangsorolását foglalja magában.
} 
és helyi pályázatot azonosítottak. Ezek köré adott célpopuláció és téma-fókuszú munkacsoportokat alakítottak ki, melyekhez egyre szélesebb körben csatlakoztak és alakítottak ki együttmúködéseket a helyi szereplők, úgy, mint az egyetemi kutatócsoportok/intézetek, az alapellátási egészségügyi szolgáltatók, népegészségügyi és közösségi-alapú szervezetek, iskola-étkeztetési szolgáltatók, környezetvédők és egyéb érdekelt felek. A városi önkormányzat Népegészségügyi Osztálya már ebben a korai fázisban a téma iránti elköteleződéséről tett tanúbizonyságot.

A SUS program megvalósítására 2002-tôl került sor, amikor is az előkészítési fázisban megtervezett három projekt, a kisiskolás gyermekek egész napját az egészséges életmód köré szervező „Shape Up Somerville" [1. ábra], az iskoláskorúak zöldség- és gyümölcsfogyasztását ösztönzo „Growing Healthy” [2. ábra], valamint a lakosság egészséges választását elősegítő városi infrastruktúra- és kapacitásfejlesztést célzó „Active Living by Design” útjára indult. Ebben az időszakban nagy figyelmet fordítottak a kapacitásépítésre és a közösségek bevonására; előbbi az iskolai személyzet, a napközis és testnevelő tanárok, a menzán dolgozók továbbképzése, oktatása révén, míg utóbbi a városi lakosság, ifjúság önkéntes munkába (pl. parkrendezés) történő bevonásával valósult meg. Felismerték, hogy a hosszú távú elköteleződés csak akkor alakul ki, ha a közösségek, szervezetek és egyéb érdekelt felek a projektmunka teljes folyamatában, a tervezéstől kezdve a megvalósításon át egészen az eredmények monitorozásáig, értékeléséig, aktívan részt vesznek. A fázis végén, 2005 körül alakult ki a szemlélet, mely szerint a különböző projekteket érdemes volna egy programként kezelni. A "Táplálkozás és fizikai aktivitás" munkacsoport átnevezésével született "SUS munkacsoport" újabbnál újabb támogatási lehetőséget kutatott fel a fenntarthatóság szempontjait szem előtt tartva, melyeket sikeresen megpályázott.

1. ábra: A SUS programhoz csatlakozó nemzetközi konyhák éttermei az egészséges választás megkönnyitése érdekében az étlapjukon feltüntetik az ételek egészséges összetevőit. A programban részt vevő éttermeket sajátos logóval jelölik.

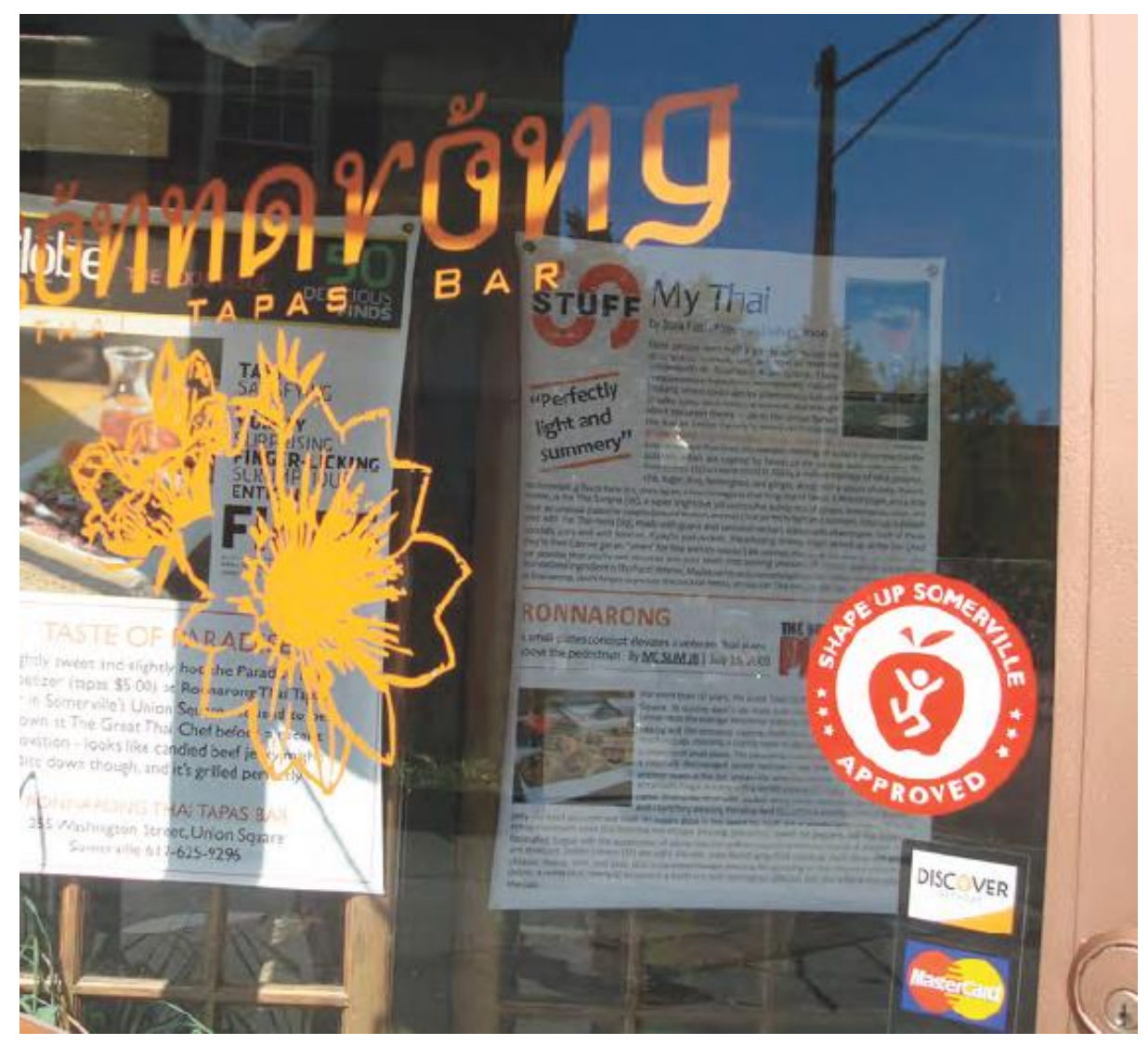

Forrás: Chomitz VR et al., 2013 
2006-tól kezdődően a SUS program látószöge kiszélesedett, ebből adódóan - nem feledve a kezdeti fő célkitǔzést, az egészséges táplálkozás és aktív életmód előmozdítását - egyre több projekt fókusza eltolódott az épített környezet, az infrastruktúra és a szakpolitika fejlesztés irányába. Ebben az időszakaszban indult a "Green Line Extension" projekt, mely Somerville és Medford regionális közlekedését élénkítené a közúti gyorsvasút vonal meghosszabbítása révén. Továbbá a városi gyalogos-, a kerékpáros- és tömegközlekedés is hatalmas fejlődésen ment keresztül ekkor. Ebben az időben a SUS program intézményesülése tetten érhető azáltal, hogy az önkormányzat átvette az irányítást, így a finanszírozást felügyelő és azt átszervező igazgatói pozíciót hozott létre, valamint a korábban már meglévő koordinátori, és a gyalogos-kerékpáros közlekedés tervezéséért felelős pozíciót is az önkormányzat feladatkörében tartotta meg. A SUS program második fázisának iskolai egészségfejlesztésben elért pozitív eredményeit 2007 májusában az Obesity folyóiratban közölték, és a Wall Street Journal mellett egyéb médiumok is foglalkoztak a program áttörő sikereivel, így a szakmai elismerésnek köszönhetően újult erővel és kitartó lelkesedéssel folytatták tovább a munkát.

2. ábra: Zöldség- és gyümölcskóstoltatás a „Growing Healthy” projekt keretében

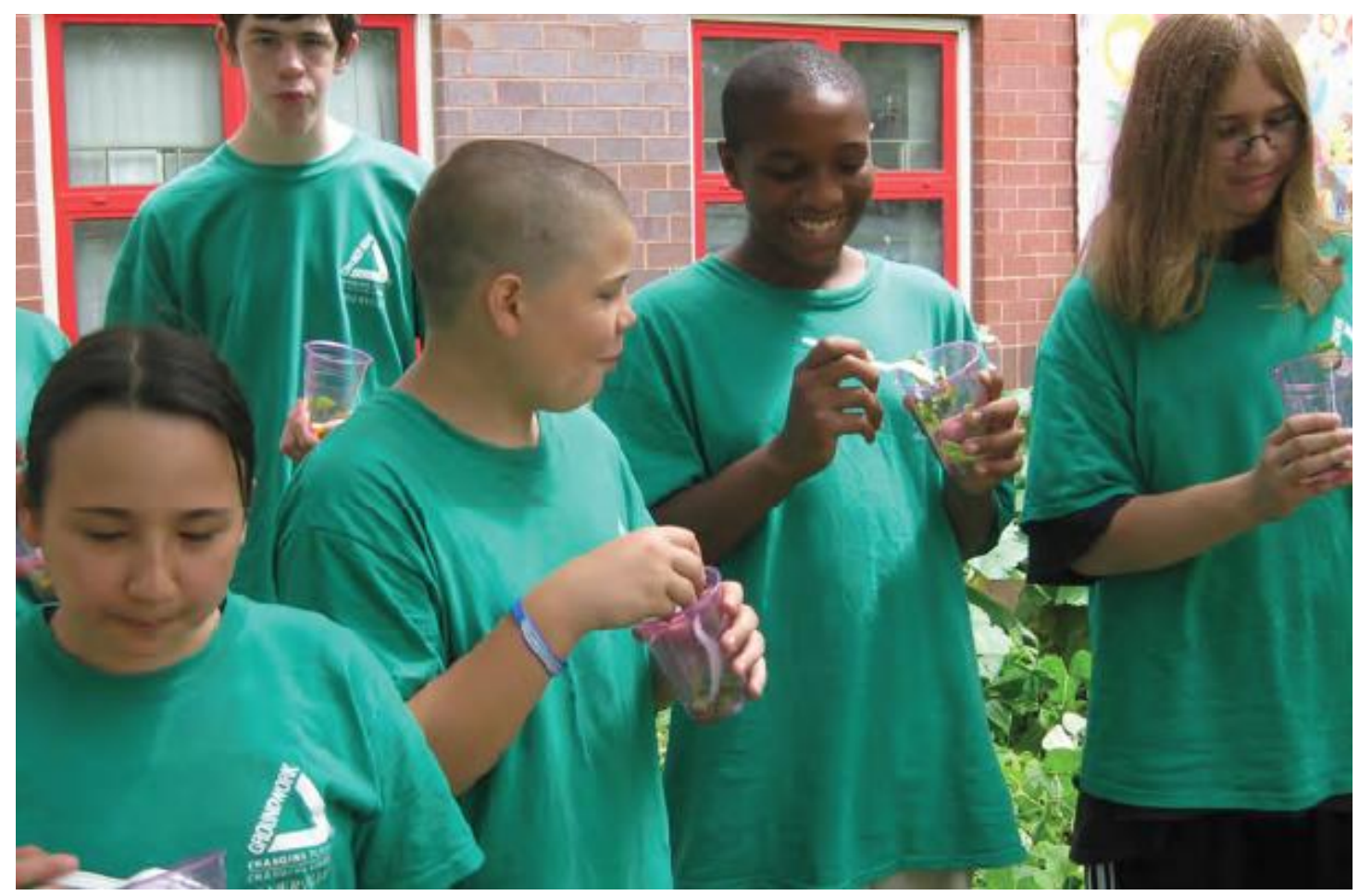

Forrás: Chomitz VR et al., 2013

A SUS program 2010-től kezdődően napjainkig modern korát éli, ahol a hangsúly egyre inkább áttevődik a közösségi színterek (pl. játszóterek, parkok) fejlesztésére, és nagyobb figyelmet fordítanak az egészségegyenlőtlenségek csökkentésére. A finanszírozás fenntarthatóságát az egyéb állami és regionális kezdeményezésekhez, együttmúködésekhez történő csatlakozás biztosítja, mint például a Michelle Obama nevéhez füződő, minden lakos számára a friss és egészséges élelmiszerek elérhetővé tételét ösztönző „Let's move!” programban való részvétel, vagy a metró közeli Hubway közbringarendszer kibővítése [3. ábra]. Napjainkban már megfigyelhető a SUS célkitǔzéseinek más szektorokban, városi ügynökségek körében való terjedése is. Kijelenthetjük, hogy mostanra a somervillei kultúra és közösség egy fontos meghatározójává az egészség szempontjainak figyelembe vétele vált. 
3. ábra: A bostoni régióban müködő Hubway közbringarendszer 2 éves időtávra tervezett kibővitése Somervillet is érinti

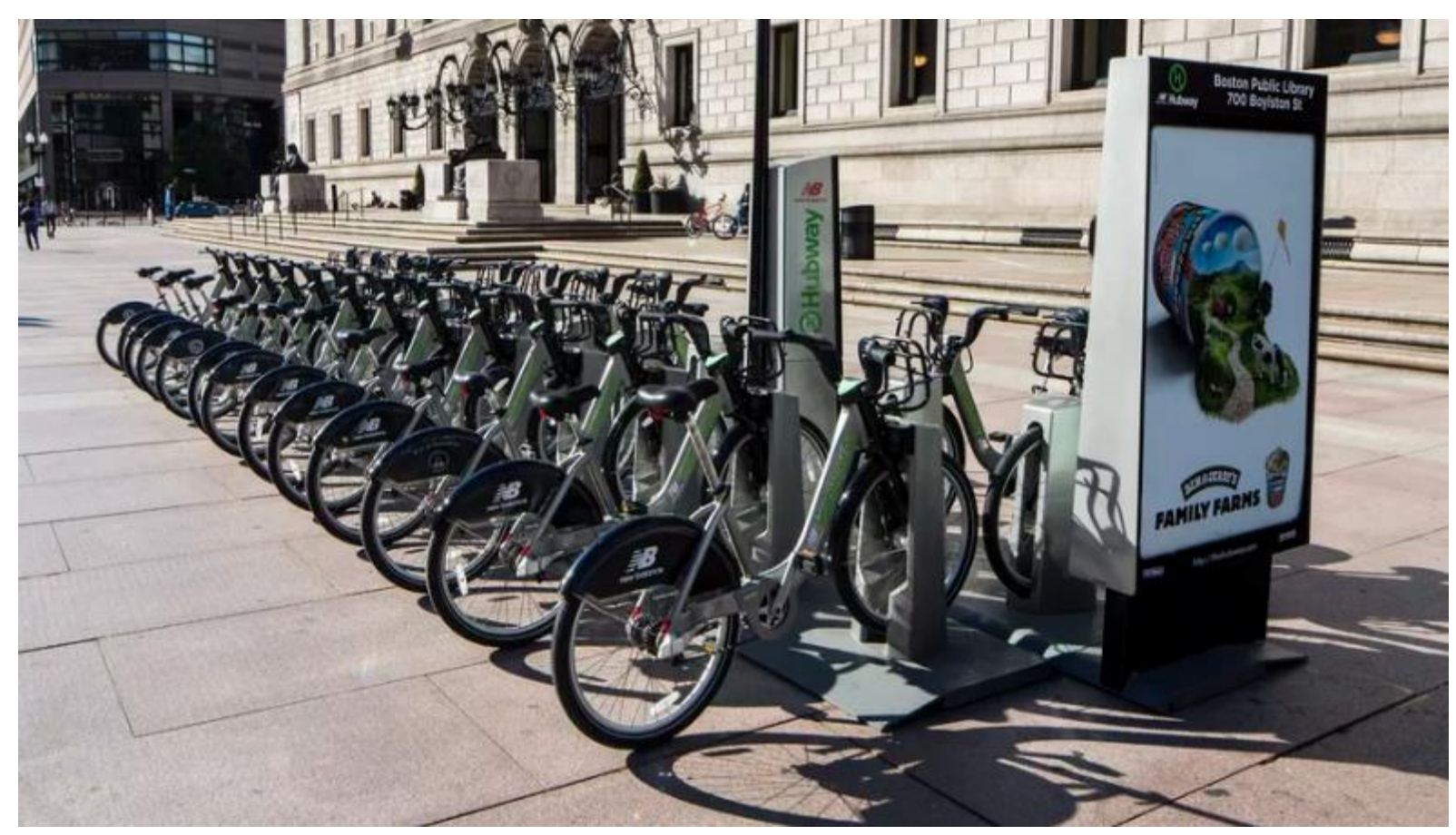

Forrás: boston.curbed.com, $2017^{2}$

\section{TANULSÁGOK A HAZAI SZAKEMBEREK SZÁMÁRA}

A SUS programról szóló riport a sikeresség talán egyik legfontosabb alapköveként említi a korai fázisban kialakuló politikai akaratot és elköteleződést, melyet Somerville polgármestere és az önkormányzati alkalmazottak személyes képzési programba történő bevonásával, valamint az aktív és egészséges életmódot ösztönző önkormányzati munkahelyi jóllét-kezdeményezés kifejlesztésével értek el. A kérdés számunkra az, vajon birtokában vagyunk-e azon kommunikációs szakértelemnek (vagy a népegészségügy terén jártas kommunikációs szakembereknek), amellyel (akik segítségével) a döntéshozók figyelme és elhivatottsága a prevenció fontosságára irányítható?

Összességében tehát egy népegészségügyi problémát - jelen esetben az elhízást - célzó megelőzési program csak akkor lehet hosszú távon eredményes, ha annak elemei pozitív irányba képesek befolyásolni a lakosság egészségmagatartását és egészségkultúráját.

\section{HIVATKOZÁSOK}

\footnotetext{
1 Túri G, Vitrai J. A közösségi egészségtervezés módszertana. IME. 2015; 14(3):11-14.

2 https://boston.curbed.com/2017/5/26/15696770/hubway-new-stations-boston-brookline-cambridge-somerville (Utoljára hozzáférve: 2018.04.22)
} 